\title{
Penerapan Mesin Roaster Kacang Tanah Untuk Peningkatan Produksi Pada Home Industry Kacang Goreng
}

\author{
Sanny Andjar Sari ${ }^{1}$, Julianus Hutabarat ${ }^{2}$, Salammia LA $^{3}$,Sri Indriani ${ }^{4}$ \\ ${ }^{1}$ Teknik Industri, Institut Teknologi Nasional Malang \\ ${ }^{2}$ Teknik Industri, Program Pascasarjana, Institut Teknologi Nasional Malang \\ ${ }^{3,4}$ Teknik Industri, Institut Teknologi Nasional Malang \\ * E-mail sesuai dengan: sannysari@ lecturer.itn.ac.id
}

\begin{abstract}
Abstrak
Home industry yang terletak di Jl. Sidoluhur RT 07 RW 01, Kepanjen - Malang, bergerak dalam industry olahan pangan yaitu kacang goreng. Pada proses pembuatan kacang goreng salah satu tahapannya yaitu proses penyangraian, dimana pada proses penyangraian tersebut masih menggunakan wadah yang terbuat dari tanah liat dengan bahan bakar kayu sehingga membutuhkan waktu sangat lama yaitu $1-2$ jam untuk $2 \mathrm{~kg}$ kacang tanah sedangkan permintaan pasar dalam sehari dapat mencapai 30 $\mathrm{kg}$ kacang tanah.Posisi penyangraian kacang tanah beban terberat terdapat pada punggung pekerja karena dilakukan dengan duduk yang sangat rendah, sehingga bagian punggung pekerja akan mudah sakit dan lelah, wadah penyangrai kacang dengan bahan bakar kayu untuk saat ini masih sangat sederhana sehingga tidak dapat memenuhi jumlah permintaan konsumen karena proses penyangraian menggunakan wadah penyangrai dari bahan tanah liat yang berbahan bakar kayu tersebut sangat lama. Karyawan yang bekerja di home industry tersebut hanya ada 2 orang sehingga untuk dapat menghasilkan produksi dalam jumlah yang banyak akan kekurangan tenaga.
\end{abstract}

Kata kunci : Mesin Roaster, Proses Penyangraian, Kacang Tanah

\section{Pendahuluan}

Perkembangan teknologi pada saat ini begitu pesat mulai dari segi informasi maupun dalam segi perindustrian maka dari itu di sangat di perlukan pemikiran - pemikiran yang inovatif serta kreatif tentang sebuah teknologi tepat guna mulai dari : pertanian, home industri bahkan sampai industry besar.Home industry yang terletak di J1. Sidoluhur RT 07 RW 01, Kepanjen - Malang bergerak dalam industri olahan pangan yaitu "Kacang Goreng" home industry ini berdiri mulai tahun 2000 oleh Ibu Fitri dimana dalam proses pembuatan kacang goreng terdapat proses penyangraian dengan menggunakan wajan yang terbuat dari tanah liat untuk menyangrai kacang kulit dengan bahan bakar kayu.

Pada dasarnya penyangraian kacang kulit menggunakan wadah yang terbuat dari tanah liat yang berbahan bakar kayu tersebut memakan waktu sangat lama yaitu $1-2$ jam hanya dapat menghasilkan 2 $\mathrm{kg}$ kacang goreng sedangkan permintaan pasar dalam sehari dapat mencapai $30 \mathrm{~kg}$ kacang goreng. Posisi penyangraian kacang tanah menjadi kacang goreng, beban terberat terdapat pada punggung pekerja karena dilakukan dengan duduk yang sangat rendah, sehingga bagian punggung pekerja akan mudah sakit dan lelah, tungku penyangrai kacang dengan bahan bakar kayu untuk saat ini masih sangat sederhana sehingga tidak dapat memenuhi jumlah permintaan konsumen karena proses penyangraian menggunakan wadah penggorengan berupa wajan dari tanah liat yang berbahan bakar kayu tersebut sangat lama. Pekerja yang terdapat di home industry tersebut hanya ada 2 orang sehingga untuk dapat menghasilkan produksi yang banyak terlalu memakan tenaga bagi pekerja.

Proses penyangraian kacang tanah saat ini masih membutuhkan waktu yang cukup lama dan dengan kapasitas produksi $1-2$ jam tersebut hanya dapat menggoreng $2 \mathrm{~kg}$ kacang tanah, sedangkan 
permintaan pasar dalam sehari dapat mencapai $30 \mathrm{~kg}$ kacang tanah. Selain itu posisi penyangraian kacang tanah beban terberat pada punggung pekerja karena pada proses penyangraian dilakukan dengan duduk yang sangat rendah, sehingga bagian punggung pekerja akan mudah sakit dan lelah. Wadah penggorengan berupa wajan dari tanah liat yang berbahan bakar kayu untuk saat ini masih sangat sederhana sehingga tidak dapat memenuhi jumlah permintaan konsumen.Dari kondisi tersebut perlu dilakukan suatu pengembangan desain mesin roaster (penyangrai) kacang tanah untuk mempercepat dan menyamankan operasional pengguna dalam hal ini para pekerja pada home industry kacang goreng tersebut.

\section{Metode Pelaksanaan Pengabdian Kepada Masyarakat}

Menyadari adanya potensi dan permasalahan dari home industry kacang goreng yang terdapat di Kabupaten Malang, maka dipandang perlu untuk mengadakan kegiatan yang menunjang program ini, dengan memberikan Penyuluhan Perancangan dan Pembuatan Mesin Roaster (Penyangrai) Kacang Tanah menjadi kacang goreng, serta pelatihan cara menggunakan mesin tersebut.

\section{Kegiatan}

1. Menerapkan IPTEK dari Perguruan Tinggi kepada masyarakat.

2. Ikut membantu pemerintah melalui peningkatan usaha olahan pangan.

3. Home Industry Kacang Goreng Kabupaten Malang dengan cara yang sama dapat mengajarkan dan menerapkan penggunaan Mesin Roaster (Penyangrai) kacang tanah menjadi kacang goreng kepada UMKM lainnya, dan masyarakat di sekitar yang membutuhkan.

4. Peningkatan efisiensi usaha olahan pangan melalui inovasi unggul dan berdaya saing.

5. Mesin dapat berjalan dan berfungsi sehingga dapat membantu Home Industry Kacang Goreng Kabupaten Malang dalam menjalankan usahanya.

\section{Partisipasi mitra dalam pelaksanaan program Iptek Bagi Masyarakat}

Khalayak sasaran yang dianggap strategis untuk dilibatkan dalam program penerapan Ipteks adalah Home Industry Kacang Goreng Kabupaten Malang, selanjutnya dapat disebarluaskan hasil kegiatan pada home industry atau UMKM khalayak sasaran lainnya. Pihak-pihak yang terkait dengan produksi Kacang Goreng ini dengan adanya penggunaan Mesin Roaster (Penyangrai) Kacang Tanah menjadi kacang goreng adalah sebagai berikut :Home Industry ataupun UMKM yang bergerak di bidang pembuatan Kacang Goreng Kabupaten Malang dan sekitarnya.

\section{Hasil dan Pembahasan}

Perancangan fasilitas kerja pada perusahaan yang dapat memenuhi syarat saat dioperasikan harus memiliki penampilan yang baik, memenuhi standart performance yang ditetapkan, tingkat keandalan yang cukup tinggi, sedang optimal penggunaannya tergantung pada aktivitas tenaga kerja untuk memanfaatkan rancangan fasilitas kerja tersebut.Pada kegiatan pengabdian ini akan dibuat mesin roaster (penyangrai) kacang tanah yang menggunakan motor listrik untuk menggerakkan mesin roaster (penyangrai) dan sumber bahan bakar menggunakan LPG $3 \mathrm{~kg}$. Dengan adanya mesin roaster (penyangrai) ini diharapkan dapat mempercepat waktu proses penyangraian kacang tanah menjadi kacang goreng. Berdasarkan rumusan permasalahan yang dihadapi oleh mitra maka tujuan pengabdian yang akan dicapai yaitu :

1. Mempercepat proses penyangraian kacang tanah menjadi kacang goreng.

2. Hasil penyangraian lebih merata sehingga dapat meningkatkan kualitas kacang goreng.

3. Meningkatkan hasil produksi dari home industry kacang goreng.

Mesin penyangrai dengan bahan bakar LPG, mengapa lebih memilih menggunakan bahan bahan LPG karena bahan bakar LPG lebih praktis dari pada menggunakan kayu bakar serta tidak 
menimbulkan polusi udara seperti debu.Dan juga mempunyai beberapa komponen, diantaranya adalah sirip yang di gunakan untuk mengaduk kacang agar matang merata secara sempurna, thermostat untuk mengatur suhu otomatis yang benggunakan daya listrik.

Perencana menggunakan mesin penyangrai otomatis menggunakan listrik sebagai penggeraknya dengan ukuran 800 watt, sedangkan untuk memasukan bahan baku kacang untuk pembuatan perencana menggunakan sistem manual, yaitu dengan memasukan bahan baku kedalam corong dengan menggunakan gayung atau sejenisnya untuk proses penyangraiannya dengan menggunakan LPG sebagai bahan bakarnyaserta sirip yang di gerakan oleh motor listrik / bekerja sesuai perencana. Besarnaya suhu di dalam tabung dapat di atur otomatis dengan thermostat.Agar hasil penyangraian maksimal dan menghasilkan produk yang bagus dan berkualitas.

\section{Perbandingan Proses Produksi Lama Dan Proses Produksi Baru}

Untuk proses produksi alat lama proses penyangraian kacang tanah ini masih memakai cara manual yaitu dengan cara di sangrai secara manual menggunakan tungku pemanas dengan bahan bakar kayu bakar yang hasilnya kurang higienis dan efisien. Sehingga pada proses ini membutuhkan waktu yang lama dan kualitas yang dihasilkan kurang memenuhi standart kelayakan penjualan.

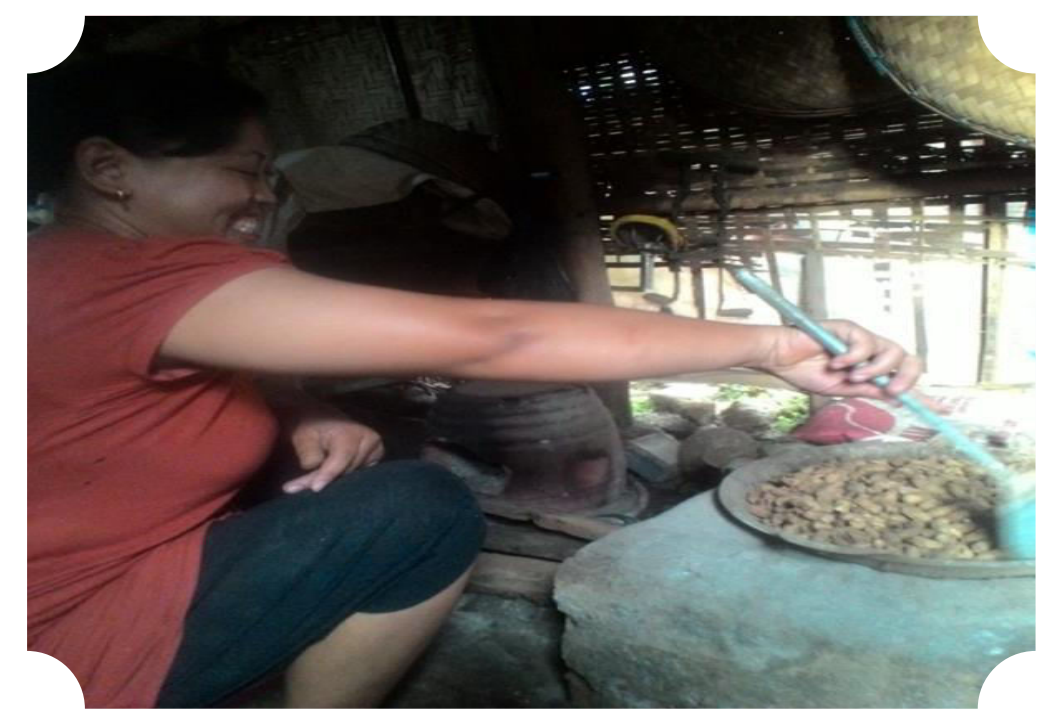

Gambar 2.Proses Penyangraian kacang tanah secara tradisional

Sedangkan untuk proses baru ini menggunakan mesin pemanas yaitu kompor gas dan pengatur suhu otomatis yang fungsinya untuk mempercepat proses pengerjaan dan menghasilkan produk yang berkualitas yang nantinya akan di pakai di sentra ukm penyangrai kacang tanah tersebut. Hal ini akan mempermudah para pelaku ukm penyangrai kacang tanah dalam proses produksi untuk memenuhi kebutuhan para konsumen.

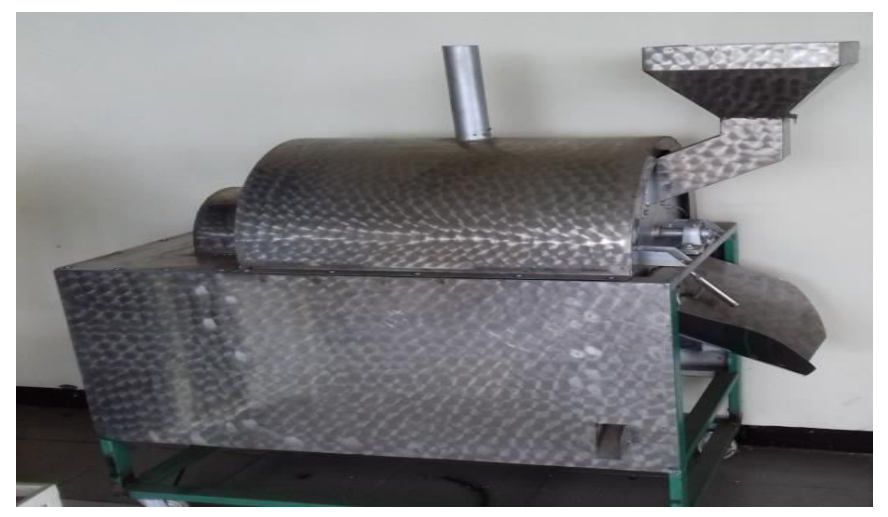

Gambar 3. Mesin Penyangraian kacang tanah 
Jadi perbanding dari alat lama dan alat baru yaitu dengan alat lama yang masih mengandalkan cara manual ini untuk proses penyangrai kacang tanah yang prosesnya membutuhkan waktu yang lama dan hasil yang kurang baik, kemudian untuk alat baru ini proses penghancurannya menggunakan mesin penyangrai dengan kompor gas dan thermostat sebagai pengatur suhu sehingga alat baru ini lebih nyaman dan lebih ergonomis dan prosesnya sangat cepat

Dari mesin penyangrai kacang tanah yang baru memiliki panjang $100 \mathrm{~cm}$, tabung berdiameter $57 \mathrm{~cm}$, dan tinggi $120 \mathrm{~cm}$ diperoleh waktu normal sebesar 16menit / kg sehingga menghasilkan output standard sebesar $6 \mathrm{~kg} / \mathrm{jam}$. Dengan melihat data-data yang diperoleh jadi didapat kenaikan persentase sebesar $900 \%$. Dengan waktu normal alat lama yang diperoleh dari penelitian sebesar 34 menit $/ \mathrm{kg}$ sehingga mendapatkan output standard sebesar $2 \mathrm{~kg} / \mathrm{jam}$.

\section{Kesimpulan}

Dari hasil kegiatan penelitian yang telah dilaksanakan memberikan kesimpulan bahwa operasional mesin penyangrai kacang tanah ini lebih efisien dan lebih ergomonis di bandingkan dengan mesin lama ( cara manual ).Desain mesin penyangrai kacang tanah menciptakan rasa aman dan nyaman bagi operator kerja.

\section{Daftar Pustaka}

[1] Panero Julianus, Zelnik Martin. 2003. Human Dimension And Interior Space, London.

[2] Ulrich, Karl T. and Steven D, Eppinger. 2001. Perancangan dan Pengembangan Produk. Jakarta: Salemba Teknik.

[3] Widodo, Imam Djati, 2005, Perencanaan dan Pengembangan Produk, UII Press, Yogyakarta.William Mendenhall, Statistics for engineering and The Sciences, third edition, Universitas of South Florida.

[4] Wignjosoebroto.S,, 2003. Ergonomi Studi Gerak Ruang dan Waktu. Guna Widya. Surabaya. 